\title{
FAILURE MODES DETERMINING THE RESISTANCE AND THE STABILITY OF STEEL CELLULAR BEAMS
}

\begin{abstract}
Effective failure modes relating to the steel cellular beams that nowadays have become widely used as a part of a building load-bearing structure are identified and discussed in detail. They are presented as those being critical both due to the structural resistance evaluation and due to the stability assessment. In the first case, the ultimate bending moment resistance of a whole beam in the presence of shear is estimated as well as the resistance of the beam tee section located at mid-length of the web-opening. Regarding to the verification of beam stability not only the lateral-torsional buckling is taken into consideration but also the shear buckling of the beam web and even the local instability of a web-post. Finally, the risk of the rupture of a welded joint located in a beam web-post is assessed to check if it is so small that it can be accepted by the building user.
\end{abstract}

Keywords: cellular beams, web-openings, Vierendeel bending, lateral-torsional buckling, web-post buckling.

\section{Introduction}

It is common knowledge that in modern buildings a large number of various technical installations must be accommodated inside. On the one hand, dimensions of the installation conduits, in particular those used for ventilation and air-conditioning, are frequently increased due to the growing needs of the building users. They are also sometimes forced by the appropriate standard regulations. On the second hand, however, looking from the point of view represented by the building user, it is economically advantageous to minimize the volume occupied by the technical installations as well as by the floor struc-

\footnotetext{
${ }^{1}$ Author for correspondence: Krzysztof Kuchta, Cracow University of Technology, Warszawska 24, 31-155 Cracow, phone: +48126282324, e-mail: kkuchta@pk.edu.pl.

2 Author for correspondence: Mariusz Maślak, Cracow University of Technology, Warszawska 24, 31-155 Cracow, phone: +48126282327, e-mail: mmaslak@pk.edu.pl.
} 
ture itself because usually the horizontal sections of such the installations are placed just below the ceiling. The best and the cheapest design solution that enables fulfilling all the conditions mentioned above seems to be a reinforced concrete floor supported by the steel beams with the web-openings. The beams of this type are used in steel structures probably from the thirties of the last century [1]. In addition to the above-mentioned advantageous functional characteristics such a solution allows a beam to achieve an increase in bending resistance as well as in flexural stiffness without any additional material used to form the structure. The intensive development, especially in the nineties of the last century, of the welding technologies using a computer-controlled manufacturing process has enabled the beams with the web-openings to become a product being more flexible in relation to the expectations of both the future building user and the designer. The spacing and the basic dimensions of the openings are at present the parameters that can be freely selectable by the designer (although to a limited range) according to the specific geometric constraints as well as to the load arrangement applied to the considered beam. Currently, there are at least three most commonly used standard shapes of the webopenings: hexagonal - used in the castellated beams, circular - used in the cellular beams, and curvilinear - used in the so called Angelina beams. The beams of hexagonal and of curvilinear contour of the web-openings are formed in the absence of the material waste whereas manufacturing of the beams of circular contour is always associated with generation of waste material and requires a two-step cutting operation (Fig.1).

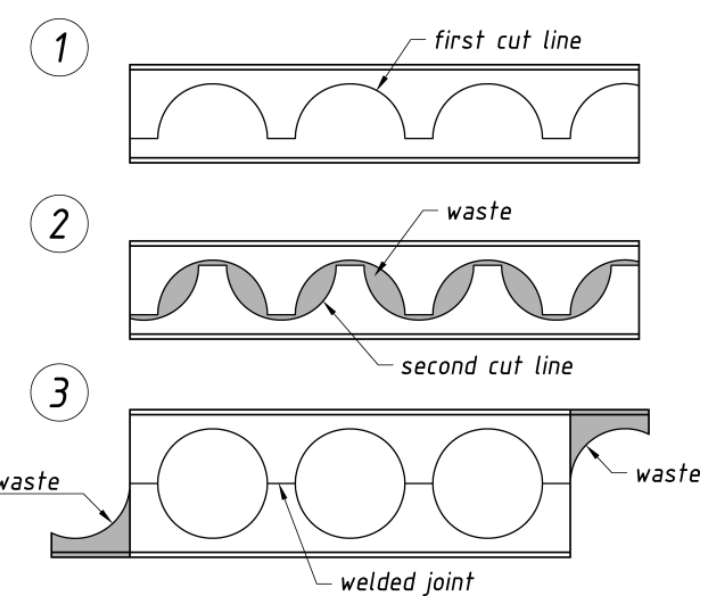

Fig. 1. Two-step cutting and manufacturing procedures of the steel cellular beams

Rys. 1. Dwa etapy procedury cięcia i wytwarzania ażurowych belek stalowych

The formal models available for the designers and helpful both in the credible evaluation of the structural resistance of the beam with the web- 
openings and in the reliable verification of the stability of such a beam are commonly known and seem to be experimentally well-justified if only these openings are hexagonally or even rectangularly-shaped [2]. However, if they relate the cellular beams with the circular web-openings then it should be noted that such models, if they exist at all, not only are not yet sufficiently verified but even they are not always unambiguously specified. In the computational approach currently being prepared for recommendation in this field by the Technical Committee CEN TC 250/SC 3 (at present the seventh draft of the appropriate standard is in preparation) some failure modes are identified for such the beams which seem to be the conclusive in structural safety assessment in the case when the persistent design situation is assumed to be considered. As a result of such identification various limit state conditions are formulated to finally have been verified whether they are fully satisfied if the considered beam is subjected to external loads. The aim of this paper is to present and to discuss in detail all the computational procedures necessary to evaluate as precisely as possible the safety level of such a beam when it is used as a part of a building structure.

\section{Static model of a cellular beam}

It is a well-known fact that if the beam has the sufficiently large and densely-spaced web-openings then the requirements relating to the prismatic rod should not be taken as fulfilled. For this reason, in practical calculations, the model of the Vierendeel beam with no diagonal members is commonly used for modelling the behaviour of cellular beams but with a simplification that the additional hinges are deployed in a mid-span of each particular component constituting the adopted structural system, as it has been proposed by Keelhof [3] (Fig. 2). Most likely this scheme the first time was used for modelling the castellated beams by Faltus as early as in 1942 [4]. In fact, this formal model is also widely used by designers when the structural response referring to the beams with rectangularly, hexagonally or even octagonally-shaped web-openings is modelled. In such cases the limit state conditions should be verified at least twice: first - in vertical sections of the compressed beam-flanges which have been imaginarily extracted from the whole beam section over the entire width of the respective web-openings, and then in horizontal sections of the respective beam web-posts, localized at the height of the upper edge of such the web-openings. The main advantage of this model is its simplicity, however, it does not allow to reflect with sufficient precise the effect of the stress concentration at the edge of the web-openings. If, however, the cellular beam is considered in the analysis, with the circular webopenings, then the effective application of that model is no longer so easy because of the difficulty in unambiguously determining the position of the critical beam cross-section. Let us note that the normal stress distribution around 
the considered web-opening is a nonlinear function of the polar coordinate $\phi$, being dependent both on the geometric parameters of the beam-cross-section and on the value of internal forces and moments which are induced in such a section [5, 6] (Fig. 3). Moreover, the place of the occurrence of extreme stresses depends on the ratio between the bending moment $M_{E d}$ and the transverse force $V_{E d}$.

Basics of such a formal model relating to the steel cellular beams are also discussed in the Polish professional literature (for example in $[7,8]$ ).

a)

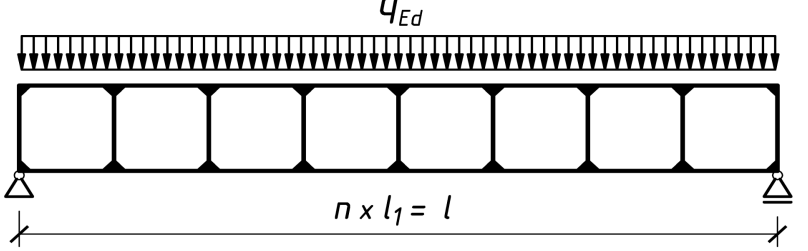

b)

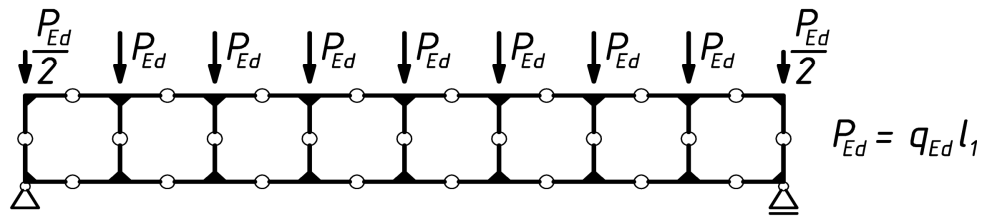

c)
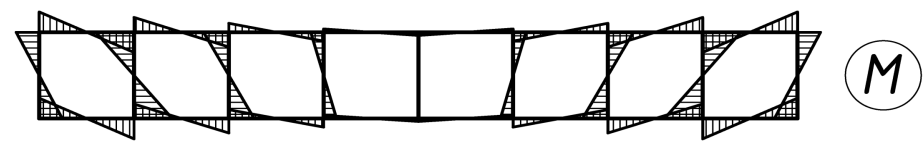

d)
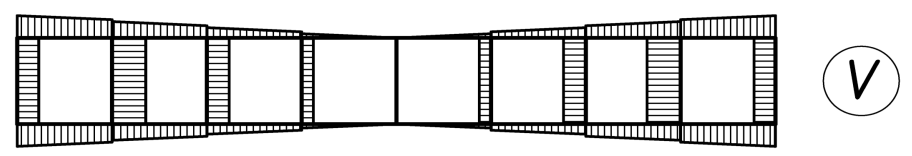

e)
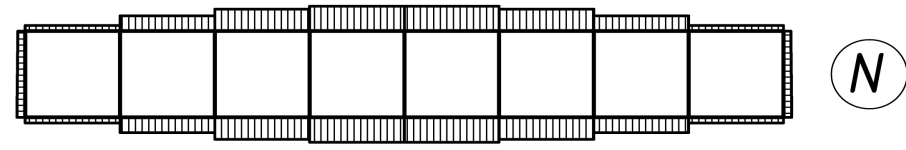

Fig. 2. Static systems generally used to model the behaviour of the beam with the web-openings: a) the classic system of Vierendeel beam, b) the simplified Vierendeel beam with the additional hinges, c) distribution of the bending moments, d) distribution of the transverse forces, e) distribution of the normal axial forces

Rys. 2. Ogólnie używane schematy statyczne do modelowania zachowania się belek ażurowych: a) klasyczny system belki Vierendeel’a, b) uproszczony model belki Vierendeel'a z dodatkowymi przegubami, c) wykres momentów zginających, d) wykres sił poprzecznych, e) wykres sił osiowych 


\section{Influence of the web-openings on the cross-section class in cellular beams}

Detailed analysis of the beam with the web-openings leads to the conclusion that the distribution of the bending moments being induced in the critical beam-cross-section depends not only on the value of the polar coordinate $\phi$ but also on the diameter of the hole weakening the beam-web. In addition, this relation, and thus the assumed class of the beam-cross-section, is depended on the effort of that part of the weakened beam-cross-section which is subjected to tension. Such dependences are a unique feature of the beam with the webopenings, unheard of in any other beams made from the sections of another kind. As a result of such beam behaviour the plastic reserve being the consequence of the redistribution of the bending moment is not available. This means that in this case one should assume that the class of the beam-cross-section is at most 2 .

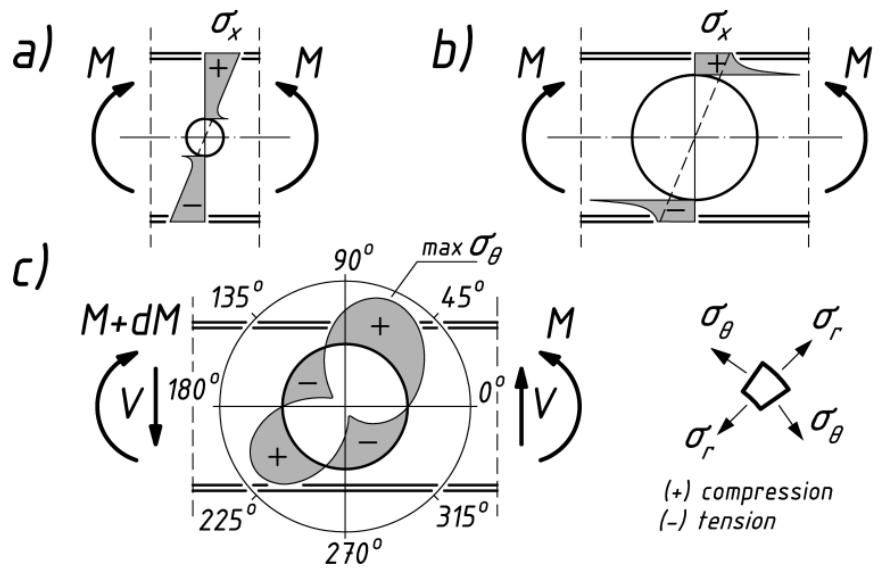

Fig. 3. Elastic stress distributions in beam-sections localized around the circular web-opening: a) normal stress $\sigma_{x}$ distribution - the case of the beam pure bending and a small webopening size according to [9], b) normal stress $\sigma_{x}$ distribution - the case of the beam pure bending and a web-opening with increased diameter according to [9], the significant stress concentrations are visible c) membrane circumferential stress $\sigma_{\theta}$ distribution along the web-opening edge - the case of the bending - shear $(\mathrm{M}-\mathrm{V})$ interaction, based on the Heller's formula according to [10]

Rys. 3. Sprężysty rozkład naprężeń na przekroju belki zlokalizowanych około kolistego otworu w środniku: a) rozkład naprężeń normalnych $\sigma_{x}$ - przypadek belki poddanej czystemu zginaniu i małej średnicy otworów w środniku według [9], b) rozkład naprężeń normalnych $\sigma_{x}$ - przypadek belki poddanej czystemu zginaniu i zwiększonej średnicy otworów w środniku według [9], widoczne są znaczne koncentracje naprężeń c) rozkład naprężeń obwodowych $\sigma_{\theta}$ wzdłuż brzegu otworu w środniku - przypadek interakcji zginanie - ścinanie (M-V), zgodnie z formułą Heller’a na podstawie [10] 
The classification of the cross-sections if it relates to the flanges being a part of the considered cellular beams can be carried out according to the classical methodology recommended in the standard EN 1993-1-1 [11]. This approach does not allow, however, to correctly determine the class of the beam-web weakened by holes. The recommendations how to classify such the weakened beam-webs were recently given in [12]. They are presented in detail in Table 1. According to this the sought cross-section class relating to the weakened beam-web can be determined based on the one of the two alternatively specified assessment criteria wherein the second of these criteria should be constitute an overriding to the first. Let us note that in the first approach the height of that part of the weakened beam-web which is subjected to compression (marked in Table 1 by the symbol $d_{t}$ because in the nomenclature proposed in the appropriate standard currently being in preparation the subscript " $t$ " denotes the top-part whereas the subscript " $b$ " denotes the bottom-part of the whole web cross-section) is additionally limited. The class of the crosssection specified for the weakened beam-web is then in the presented design procedure not only the measure of the sensitivity of such a web on the elasticplastic instability phenomena but also the measure of the flexibility of the compressed beam-flange-t-stub (such a t-stub is in the standard mentioned above named the tee-section with the length $l_{t}$ - then in this case the subscript " $t$ " denotes the name "tee") on its local flexural buckling.

Table. 1. The recommendations relating to the cellular beam-web cross-section classification weakened by holes (according to [12]), $\varepsilon=\sqrt{235 / f_{y}}$.

Tabela 1. Rekomendacje dotyczące klasyfikacji przekroju poprzecznego środnika osłabionego przez otwory w belkach ażurowych (według [12]), $\varepsilon=\sqrt{235 / f_{y}}$

\begin{tabular}{|c|c|c|c|}
\hline \multirow{2}{*}{$\begin{array}{c}\text { Class of the } \\
\text { beam web } \\
\text { cross-section } \\
\text { weakened by } \\
\text { holes }\end{array}$} & $(1 \mathrm{a})$ & $(1 \mathrm{~b})$ & \multicolumn{3}{|c|}{ Assessment criterion } \\
\cline { 2 - 4 } & $l_{t}>32 t_{w} \varepsilon$ & $d_{t} \leq \frac{10 t_{w} \varepsilon}{\sqrt{1-\left(\frac{32 t_{w} \varepsilon}{l_{t}}\right)^{2}}}$ & $\quad l_{t} \leq 32 t_{w} \varepsilon$ \\
\hline 2 & & \\
\hline
\end{tabular}




\begin{tabular}{|c|c|c|c|}
\hline 3 & $l_{t}>36 t_{w} \varepsilon$ & $d_{t} \leq \frac{14 t_{w} \varepsilon}{\sqrt{1-\left(\frac{36 t_{w} \varepsilon}{l_{t}}\right)^{2}}} \quad l_{t} \leq 36 t_{w} \varepsilon$ \\
\hline 4 & $d_{t}>\frac{14 t_{w} \varepsilon}{\sqrt{1-\left(\frac{36 t_{w} \varepsilon}{l_{t}}\right)^{2}}}$ \\
\hline $\begin{array}{c}\text { Elongated circular openings } \\
l_{t}=l_{o}-0,3 d_{o}\end{array}$ & $l_{t}>36 t_{w} \varepsilon$ \\
\hline
\end{tabular}

It should be added that the effort of that beam tee-section which is subjected to tension (i.e. that with the height $d_{b}$ ) can change the assumed class of the beam-web weakened by holes. In particular, the sections which have been initially classified in class 3 may be treated as those classified in class 2 if the following inequality is satisfied [12]:

$$
\frac{N(x)}{A_{b} f_{y}} \geq 1-\frac{20 \varepsilon t_{w}^{2}}{A_{b}}
$$

where $N(x)$ denotes the axial force induced in the bottom beam-tee-section being in tension whereas $A_{b}$ means the area of such a tee-section. Furthermore, the cross-sections classified in class 4 may be treated as those classified in class 3 if only the following occurs [12]:

$$
d_{b} \leq \frac{14 t_{w} \varepsilon^{\prime}}{\sqrt{1-\left(\frac{36 t_{w} \varepsilon^{\prime}}{l_{t}}\right)^{2}}} \quad \text { and } \quad l_{t}>36 t_{w} \varepsilon^{\prime}
$$

where:

$$
\varepsilon^{\prime}=\frac{\varepsilon}{\sqrt{1-\frac{N(x)}{A_{b} f_{y d}}}}
$$




\section{Vierendeel bending and ultimate global bending resistance evaluation}

Based on the experimentally identified beam failure modes the four-hinged failure mechanism has been proposed $[5,13]$ as that being conclusive for determining the ultimate beam resistance when the bending-shear $(\mathrm{M}-\mathrm{V})$ interaction is considered (Fig. 4). The sections selected for verification of the ultimate limit state conditions are defined here as the planar radial sections specified in the polar coordinate system centered at the center of the hole.

The inclination of the plane containing the critical cross-section, measured by the angle $\varphi$ (Fig. 5), is the value initially unknown. It is determined itera-

tively. Its value is in the range of $0^{\circ}$ in case of the beam pure bending to $28^{\circ}$ in case of the beam pure shear. As a safe estimate one may assume that $\varphi=25^{\circ}$ [13]. It should be underlined the following fact (see Fig. 5): although the assumption of the purely elastic stress distribution in the most weakened vertical cross section of the considered beam is fully satisfied it is true that in the critical beam cross-section, deviating from the previous one by the angle $\varphi$, a partial plasticizing of this section may occur as a consequence of the possible interaction $M_{\varphi}-V_{\varphi}-N_{\varphi}$.
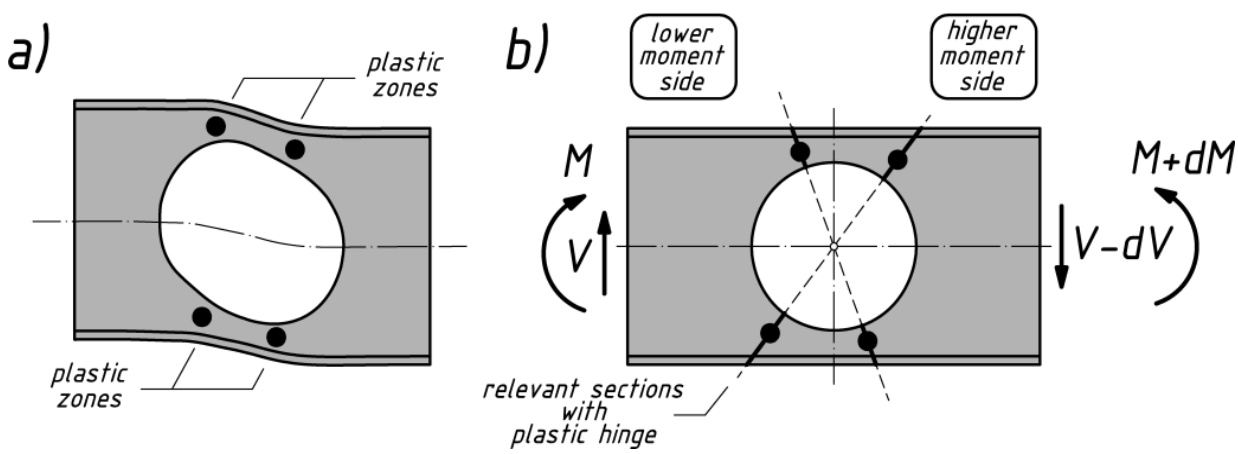

Fig. 4. Failure mode of a cellular beam when it is subjected to the M-V interaction: a) the fourhinged failure mechanism, b) location of the relevant plastic hinges

Rys. 4. Rodzaje zniszczenia belki ażurowej gdy jest ona poddana interakcji M-V: a) mechanizm zniszczenia przy powstaniu czterech przegubów plastycznych, b) lokalizacja istotnych przegubów plastycznych 


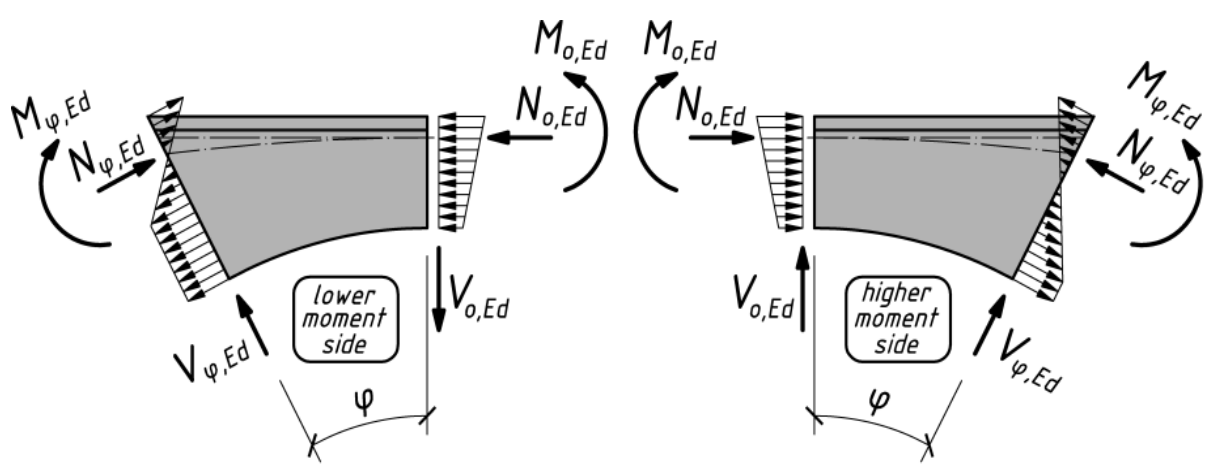

Fig. 5. Normal stress distributions at the relevant top critical tee-sections of the considered cellular beam (according to [14])

Rys. 5. Rozkład naprężeń normalnych przy odpowiednim górnym krytycznym przekroju teowym rozpatrywanej belki ażurowej (na podstawie [14])

This means that in such a critical beam tee-section the ultimate limit state condition being appropriate for its interactive resistance should be satisfied. It has been formulated as follows [14]:

$$
\frac{N_{\varphi, E d}}{N_{\varphi, R d}}+\frac{M_{\varphi, E d}}{M_{\varphi, R d}} \leq 1,0
$$

It may be noted that in the above formula the transverse force $V_{\varphi, E d}$ is not explicitly specified; however, its impact in the previously identified critical cross-section should be included by a possible reduction both in beamsection bending resistance $M_{\varphi, R d}$ and in the beam-section tension resistance $N_{\varphi, R d}$, in accordance with the requirements of the standard [13].

\section{Shear resistance of cellular beams}

The shear resistance of the beam with the web-openings is closely related to the effects of disturbances in the flow of tangential stresses in the weakened beam-web. The consequence of such disturbances is an additional in-plane bending subjected both to the critical beam-tee-cross-sections and to the beamweb-posts located between the openings. According to the recommendations given in [12] the transverse force $V_{E d}$ should be limited to the value:

$$
V_{E d} \leq \frac{2\left[M_{e l, a, w p, R d} / s+2 M_{N, b, R d} / \ell_{o}\right]}{\left[1+2 e_{0} / h_{e f f}\right]}
$$


where $M_{e l, a, w p, R d}$ denotes the design value of the elastic bending resistance of the beam web-post located between the openings. Its value can be calculated as follows:

$$
M_{e l, a, w p, R d}=\frac{s_{0}^{2} t_{w} f_{y d}}{6}
$$

In such a formula $s_{0}$ is the minimum width of a web-post. Furthermore, $M_{N, b, R d}$ denotes in formula (5) the bending resistance of the bottom web-teesection, but reduced because of the impact of the tensile force $N_{a, b}$ inducing in such a section as a consequence of the global bending of the considered beam. The remaining symbols refer to only the geometrical quantities; in particular, $e_{0}$ is the eccentricity of the centre of the considered web-opening measured with respect to the horizontal axis of the whole beam, whereas $h_{\text {eff }}$ is the distance between the centres of gravity of the two corresponding beamtee-sections, i.e. the top and the bottom, measured with respect to the most weakened beam cross-section. The limitation given in formula (5) is mainly due to the limited bending resistance of the beam web-posts.

The other restriction determining the shear resistance of the beam with the web-openings is this associated with in-plane shear of such the considered web-post. This shear is the second-order action resulted from the variation of the bending moment value along the beam length (Fig. 6). The design value of the horizontal transverse force induced as a consequence of the web-post inplane shear can be evaluated directly from the equilibrium equation relating to the single segment of the simplified static scheme shown in detail in Fig.1. This gives the following formula:

$$
V_{w p, E d}=\frac{V_{\mathrm{Ed}} S}{h_{\mathrm{eff}}}
$$

On the other hand, the shear resistance of such a web-post is determined for its smallest horizontal section, then the following occurs:

$$
V_{w p, R d}=s_{o} t_{w} f_{y d} / \sqrt{3}
$$

Because the safety condition $V_{w p, E d} \leq V_{w p, R d}$ must be satisfied, then finally the following limitation can be specified: 


$$
V_{E d} \leq \frac{s_{o} t_{w} h_{e f f} f_{y d}}{s \sqrt{3}}
$$

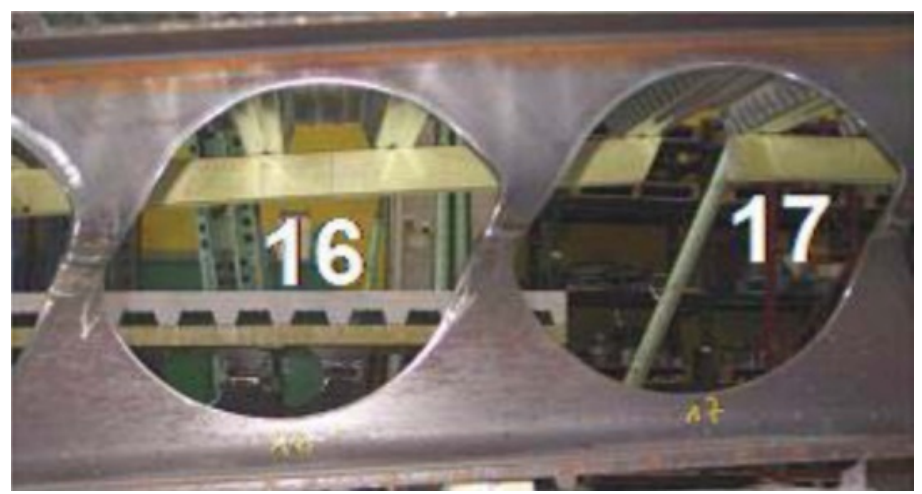

Fig. 6. Web-post failure mode in cellular beam resulted from the in-plane shear of such a webpost (photo taken from the thesis [15] accessible in [24])

Rys. 6. Rodzaj zniszczenia słupków środnika w belce ażurowej wywołane ścinaniem w płaszczyźnie środnika (fotografia z dysertacji [15] dostępna w [24])

\section{Buckling resistance of the beam web-post}

Destruction of the beam with the web-openings can also occur as a consequence of the instability of a single web-post. The hole disrupts a flow of tangential stresses in the beam-web causing their local accumulations especially near the hole edges, which may result in local elastic-plastic instability of the beam web-posts which usually manifests itself by the creation of the bulges, as it is shown in detail in Fig. 7b. It can be seen that the line connecting the apexes of such bulges determines a general direction of the trajectory of compressive stresses. Currently at least two alternative design approaches are recommended to be used to verify whether the stability of the beam web-post will be preserved. The first of these is the general method which can be used regardless of the shape of the web-openings while the other is calibrated only for beams having the circularly-shaped holes. According to the general method it was found that the stability of the beam web-post does not need to be checked if the limitation $d_{0} / t_{w} \leq 25$ is fulfilled. Otherwise, the buckling of the web-post can be analysed based on the distribution of compressive stresses resulting from the action of the effective horizontal force which is quantitatively determined from the equation:

$$
V_{w p, E d, e f f}=V_{w p, E d} \pm 2 \frac{M_{w p, E d}}{d_{0}}
$$


for the top and for the bottom beam tee-sections separately, where $V_{w p, E d}$ is the design value of the horizontal shear force while $M_{w p, E d}$ the design value of the bending moment both inducing themselves in the beam web-post. The compressive stresses in the beam web-post can be set to be equal to the average tangential stresses calculated as follows:

$$
\sigma_{w p, E d}=\frac{V_{w p, E d}}{s_{0} t_{w}}
$$
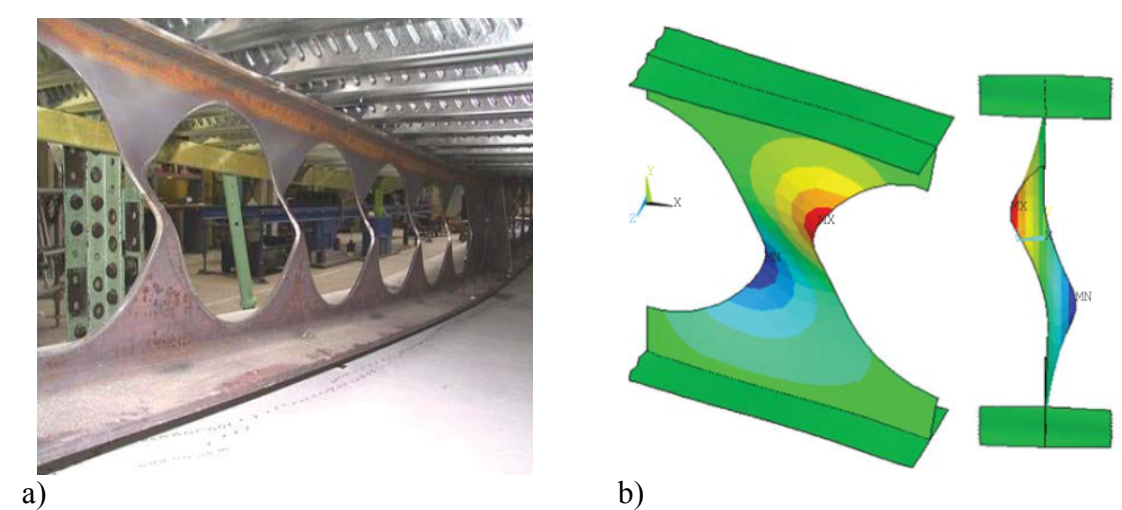

b)

Fig. 7. Web-post buckling in a cellular beam: a) obtained experimentally by Vassart with the team (the results of such the experiments are reported in detail in [16]), b) modelled numerically (according to the example presented in [17])

Rys. 7. Wyboczenie słupków środnika w belce ażurowej: a) otrzymane z badań Vassarta z zespołem (wyniki tych badań zostały dokładnie przedstawione w [16]), b) modelowane numerycznie (według przykładów zaprezentowanych w [17])

The buckling resistance of the beam web-post is calculated by specifying the design value of the ultimate stress level, maximum possible to accept. It is defined as follows:

$$
\sigma_{b, w p, R d}=\frac{\chi_{w p} f_{y d}}{\gamma_{M 1}}
$$

The web-post buckling coefficient $\chi_{w p}$ is determined for fictitious bar representing a compressed web band between adjacent openings. To do this the equivalent relative slenderness is specified, being calculated from the following equation:

$$
\bar{\lambda}=\frac{1,75 \sqrt{s_{0}^{2}+d_{0}^{2}}}{t_{\mathrm{w}}} \frac{1}{\lambda_{1}}
$$


where:

$$
\lambda_{1}=\pi \sqrt{\frac{E}{f_{\mathrm{y}}}}=93,9 \varepsilon
$$

The value of the coefficient $\chi_{w p}$ should be calculated in relations to the curve „, $b "$, as it is recommended in the standard [11]. Finally, the webpost stability condition has the form:

$$
\sigma_{w p, E d} \leq \sigma_{b, w p, R d}
$$

Regardless of the shape of the web-openings the transverse force generated in a beam should fulfill the following restriction resulting from the Vierendeel bending:

$$
V_{E d} \leq \frac{\left[\sigma_{b, w p, R d} t_{\mathrm{w}} s_{0}+4 M_{N, b, R d} / \ell_{0}\right]}{\left[1+\left(2 e_{0}+d_{0}\right) / h_{e f f}\right]}
$$

The alternative design algorithm, helpful in the verification of the stability of the beam web-post, is described in an Annex A of the standard dedicated to the cellular beams. As it has been mentioned previously such a standard is currently in preparation by the Technical Committee CEN TC 250/SC 3. However, this approach is undoubtedly much more complex and its detailed description requires a separate study. It seems that the verification performed in this alternative way should be significantly more precise and more trustworthy than this previously presented in this chapter.

\section{Lateral - torsional buckling}

The lateral - torsional buckling resistance can be evaluated for the cellular beams when they are subjected to in-plane bending on the basis of the classical formula recommended in the standard [11]:

$$
M_{b, L T, R d}=\chi_{L T} W_{y} \frac{f_{y}}{\gamma_{M 1}}
$$


a) $x_{1}$

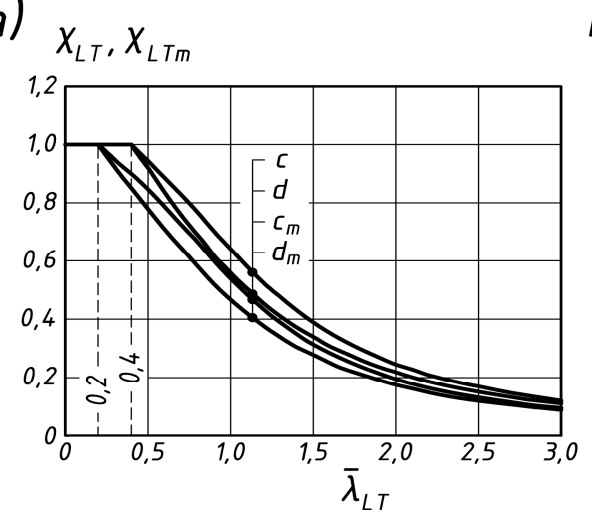

b)

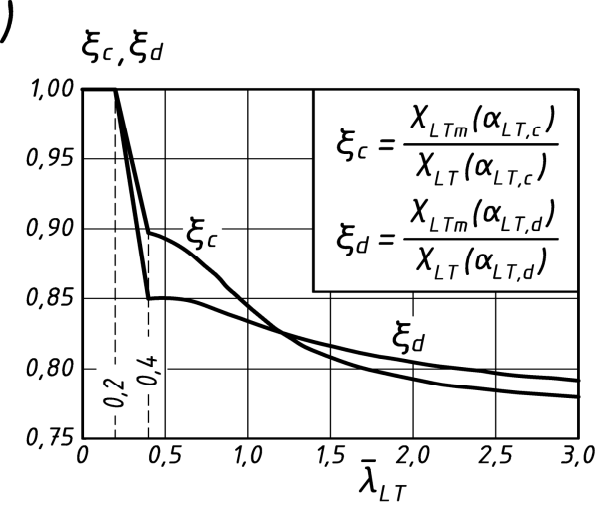

Fig. 8. Comparison of the lateral-buckling curves $c_{m}$ and $d_{m}$ proposed for the cellular beams with the appropriate curves specified in the standard [11] for the beams without web-openings: a) in the classic coordinate system, b) by using the comparative factors $\xi_{c}$ and $\xi_{d}$

Rys. 8. Porównanie krzywych zwichrzenia $c_{m}$ i $d_{m}$ proponowanych dla belek ażurowych z odpowiednimi krzywymi podanymi w normie [11] dla belek pełnościennych: a) w klasycznym układzie współrzędnych, b) przy użyciu współczynników porównawczych $\xi_{c}$ i $\xi_{d}$

a)

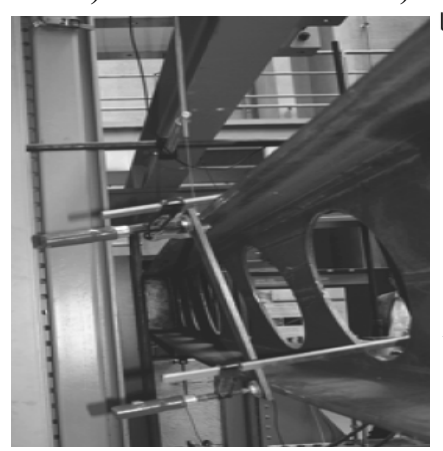

b)

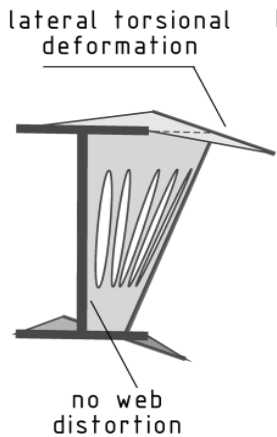

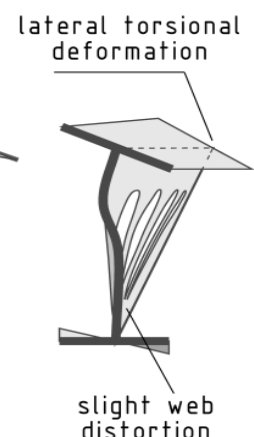

distortion

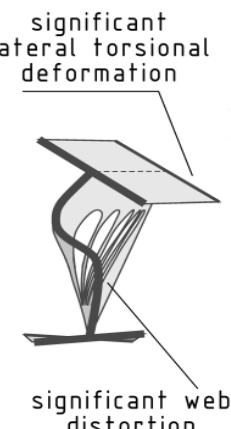

significant teral torsional deformation

distortion

Fig. 9. Lateral-torsional buckling of a cellular beam: a) observed experimentally by Vassart with the team (the results of such the experiments are reported in detail in [18]), b) phases of a beam failure, subsequent deformation schemes: in the foreground - for the near-support section, in the background - for the mid-span section (scheme elaborated according to the model given in [19])

Rys. 9. Zwichrzenie belki ażurowej: a) obserwowane podczas badań Vassarta z zespołem (wyniki tych badań zostały dokładnie przedstawione w [168]), b) fazy zniszczenia belki, kolejne schematy deformacji: na pierwszym planie - przekrój w pobliżu podpory, na dalszym planie - dla przekroju w środku rozpiętości belki (schematy opracowano na podstawie modelu podanego $\mathrm{w}[19])$ 
In such a formula the bending modulus $W_{y}$ is determined for the section located in the axis of the web-opening, being in general this the most-weakened, and having regard to the modified way of determining the class of the crosssection because of the presence of the web-opening. The instability coefficient $\chi_{L T}$ may be calculated in accordance with the traditional standard procedure given in [11] provided that the value of the imperfection parameter $\alpha_{L T}$ will be adopted to be equal to 0,49 (i.e. according to the buckling curve "c") if the beam is made of a hot-rolled double-tee steel section or to be equal to 0,76 (i.e. according to the buckling curve " $d$ ") if the beam is made of the only monosymmetrical steel sections. It should be underlined that the values relating to the ultimate slenderness $\bar{\lambda}_{L T}=\bar{\lambda}_{L T, 0}=0,2$ (in place of the traditional value $\bar{\lambda}_{L T, 0}=0,4$ - see Fig. 8) as well as to the auxiliary parameter $\beta=1,0$ (in place of the traditional value $\beta=0,75$ ) differ from those given in the standard [11].

A specific feature of a lateral - torsional buckling of cellular beams is the occurrence of the coupled instability modes combining the flexural - torsional and the distorsional instability forms. The lateral - torsional buckling of the beam in a mid-span, i.e. outside the neighbourhood of the supports, occurs classically which manifest itself by the simultaneous deflection and rotation of the cross-section, whereas at the same time the sections located at the regions adjacent to the supports are subjected to the distorsion coupled with the instability of the web-posts. The similar coupled failure modes were observed experimentally by Giżejowski and Salah $[20,21]$ but in relations to the composite floor beams. The distorsion identified there was associated with forcing the lateral displacements of the compressed part of the beam crosssection.

\section{Rupture of the welded joint in a web-post}

If the distance between the adjacent web-openings and thus the effective width of the considered web-posts are small enough then the failure mode being decisive due to the destruction of the entire beam may prove this relating to the rupture of the weld joining the upper and the lower parts of this web-post. The internal force parallel to the axis of the considered weld and transversal in relation to the web-post is in this case the primary load applied to such a joint.

The secondary one is the beam out-of-plane bending resulting from the compression of the web-post as well as from the imperfection in a web-post verticality which may be induced by the weld shrinkage. The joints connecting both parts of the web-posts are usually performed as a double-sided butt weld, with partial weld-penetration and without pre-bevelling of the web-post edges.

Let us note that modern welding technology enables to achieve the depth of such penetration of a single weld to a maximum of $6 \mathrm{~mm}$. Dimensioning 
of the joints of the web-posts can be carried out according to the standard procedure set out in the standard EN 1993-1-8 [22].

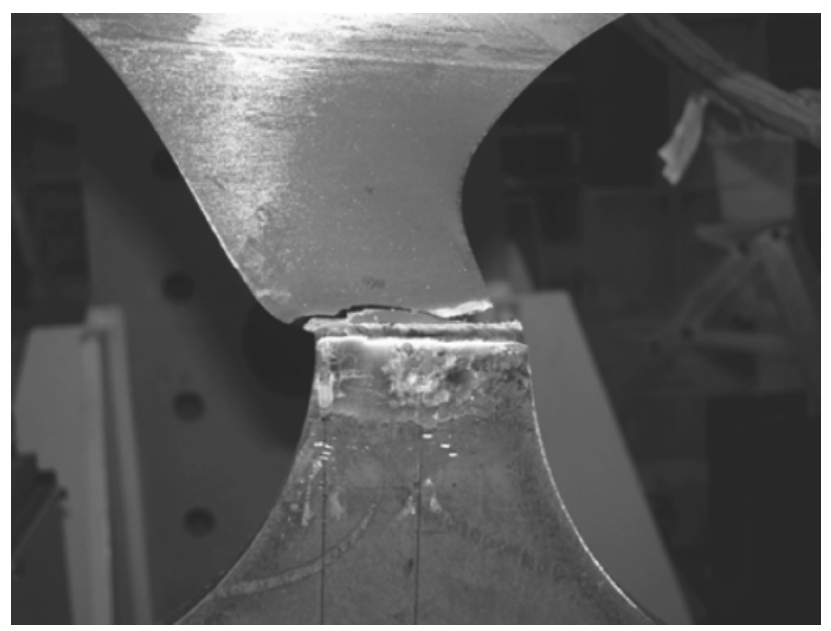

Fig. 10. Rupture of the weld in a web-post of a cellular beam (photo taken from the presentation [23] accessible in [25])

Rys. 10. Zniszczenie spoin w słupku środnika belki ażurowej (fotografia zapożyczona z prezentacji [23], dostępnej w [25])

\section{Summary}

The steel double-tee beams with circularly-shaped web-openings enjoy the growing interest both from the investors and from the designers both due to their light weight and due to the ability to be relatively easily integrated with various kinds of technical installations necessary to be placed in the building. At present, however, no recommendations how to design the beams of this type are formally specified in the relevant standards, including the appropriate Eurocodes relating to the design of steel structures. As it has been mentioned previously in the text of this paper, currently the specialized document relating to these issues is being developed by the Technical Committee CEN TC 250/SC 3. It is essential that the design procedures relating to the steel cellular beams should significantly differ from the classical standard algorithms used for dimensioning of similar steel beams but without holes. The qualitative differences should take into account not only the differences in the static analysis itself but also the specificity of the procedures relating to the identification as well as to the verification of the ultimate limit state of such a beam. This is a consequence of the fact that in such beams the specific failure modes can be activated. They are different from those typical for the ordinary steel beams, and as a result they become decisive both for the beam resistance and stability. 


\section{Bibliography}

[1] Voříšek V., Chladný E., Melcher J.: Prvky kovových konštrukcií, Alfa - Vydavatel'stvo Technickej a Ekonomickej Literatúry, Bratislava, 1983,

[2] Łubiński M., Filipowicz A., Żółtowski W.: Konstrukcje metalowe. Część 1, Arkady, Warszawa, 2000,

[3] Espion B.: The Vierendeel bridge at its heyday: Rational design, experiments and brittle failure, in: Nuts \& bolts of construction history, vol. 3, p. 253-260, Picard, Paris, 2012,

[4] Faltus F.: Prolamované nosníky. Technický obzor, vol. 50, 1942, p. 175-180 and 387-389,

[5] Chung K.F., Liu T.C.H., Ko A.C.H.: Investigation on Vierendeel mechanism in steel beams with large web openings, Journal of Constructional Steel Research, vol. 57, p. 467-490, 2001,

[6] Panedpojaman P., Rongram T.: Design equations for Vierendeel bending of steel beams with circular web openings, Proceedings of the World Congress on Engineering (WCE 2014), vol. II, July 2-4, 2014, London, UK,

[7] Łubiński M., Bródka J.: Lekkie konstrukcje stalowe, Arkady, Warszawa, 1978,

[8] Bródka J., Broniewicz M.: Projektowanie konstrukcji stalowych według Eurokodów, PWT, Rzeszów, 2013,

[9] Gere J. M.: Mechanics of materials, Sixth Edition, Thomson Learning Inc., Brooks/Cole, 2004.

[10] Redwood R. G.: Design of I-beams with web perforations, in: Narayanan R.: Beam and beam-columns: stability and strength, Applied Science Publishers, London and New York, 1983,

[11] EN 1993-1-1:2005, Eurocode 3. Design of steel structures. Part 1-1: General rules and rules for buildings,

[12] Müller C., Hechler O., Bureau A., Bitar D., Joyeux D., Cajot L. G., Demarco T., Lawson R. M., Hicks S., Devine P., Lagerqvist O., Hedman-Pétursson E., Unosson E., Feldmann M.: Large web openings for service integration in composite floors, Final report, Office for Official Publications of the European Communities, Luxembourg, 2006,

[13] Ward J. K.: Design of composite and non-composite cellular beams. The Steel Construction Institute, 1990,

[14] ENV 1993-1-1:1992/A2:1998, Eurocode 3 : Calcul des structures en acier. Partie 1-1: Règles générales - Règles générales et règles pour les bâtiments, Annexe N, Ouvertures dans les âmes,

[15] Bihina G.: Analyse du comportement au feu des planchers mixtes acier-béton constitutés de poutres cellulaires, Doctoral Thesis, Université Blaise-Pascal - Clermont II, Clermont-Ferrand, 2011,

[16] Durif S., Bouchaïr A. H., Vassart O.: Validation of an analytical model for curved and tapered cellular beams at normal and fire conditions, Periodica Polytechnica Civil Engineering, Vol. 57, No. 1 (2013), p. 83-95,

[17] Panedpojaman P., Thepchatri T., Limkatanyu S.: Novel design equations for shear strength of local web-post buckling in cellular beams, Thin-Walled Structures, vol. 76 (2014), p. 92-104, 
[18] Nseir J., Lo M., Sonck D., Somja H., Vassart O., Boissonnade N.: Lateral torsional buckling of cellular steel beams, Proceedings of the Annual Stability Conference, Structural Stability Research Council, Grapevine, Texas, April 18-21, 2012,

[19] El-Sawy K.M., Sweedan A.M.I. , Martini M.I.: Moment gradient factor of cellular steel beams under inelastic flexure, Journal of Constructional Steel Research, vol. 98 (2014), p. 20-34,

[20] Giżejowski M.A., Salah W.A.: Numerical modeling of composite castellated beams, Proceedings of the Sixth International Conference on Composite Construction in Steel and Concrete, Devil's Thumb Ranch in Tabernash, Colorado, July 20-24, 2008,

[21] Giżejowski M.A., Salah W.A.: Numerical modeling of composite castellated beams, in: Leon R.T., Perea T., Rassati G.A., Lange J. (Eds.): Composite construction and steel and concrete, American Society of Civil Engineering, Reston, USA, 2011, p. 554-565,

[22] EN 1993-1-8:2005: Eurocode 3: Design of steel structures. Part 1-8: Design of joints,

[23] Hechler O.: Fertigung von Lochstegträgern. Parkhäuser und Lochstegträger in Stahl-oder Stahlverbundbauweise, html presentation accessible in [25]

[24] https://halshs.archives-ouvertes.fr/tel-00673404/document [access: April 18,2015]

[25] http://www.stb.rwth-aachen.de/projekte/2005/LWO+/LWO+.html, [access: April $18,2015]$

\section{RODZAJE ZNISZCZENIA OKREŚLAJĄCE NOŚNOŚĆ I STATECZNOŚĆ STALOWYCH BELEK AŻUROWYCH}

\section{Streszczenie}

W artykule zidentyfikowano i omówiono szczegółowo, efektywne rodzaje zniszczenia występujące w belkach ażurowych, które obecnie są powszechnie używane jako konstrukcyjne elementy w budynkach. Zostały one przedstawione jako kluczowe ze względu na nośność belki jak i ze względu na ocenę jej stateczność. W pierwszym przypadku, została oszacowana maksymalna nośność na zginanie całej belki z uwzględnieniem siły ścinającej jako nośność przekroju teowego belki zlokalizowanego na środku otworu w środniku. W przypadku sprawdzania stateczności belki, należy brać pod uwagę nie tylko zwichrzenie belki ale także możliwość wyboczenia środnika belki poddanego ścinaniu, oraz miejscową utratę stateczności słupków środnika. W końcu, należy również sprawdzić możliwość zniszczenia połączenia spawanego w słupkach środnika belki, jednak ryzyko takiego uszkodzenia jest tak małe że może być akceptowalne przez użytkowników budynków.

Słowa kluczowe: belki ażurowe, środnik z otworami, zginana belka Vierendeel’a, zwichrzenie, wyboczenie słupków środnika

Przestano do redakcji:26.05.2015

Przyjęto do druku:10.01.2016

DOI: $10.7862 / \mathrm{rb} .2015 .194$ 